\title{
Long-term Effect of Silver Powder in vivo
}

\author{
Hidekazu AOYAGI and Shin-ich IWASAKI
}

Advanced Research Center, School of Life Dentistry at Niigata, Nippon Dental University, 1-8 Hamaura cho, Chuo-ku, Niigata 951-8580, Japan Corresponding author, Hidekazu AOYAGI; E-mail: aoy@ngt.ndu.ac.jp

\begin{abstract}
The cytotoxicity of silver is a known property of this metal. Interestingly, in the cases of argyria and tattoos, Ag remains in the tissue for a long time without causing harm to the host except pigmentation. To understand these contradictions, pure silver implantation by an original subcutaneous injection method was performed. Two sizes of silver powder particles were implanted subcutaneously: $100 \mathrm{~nm}$ (P-silver) and the maximum $45 \mu \mathrm{m}$ (G-silver). The sulfuration of silver and histopathologic changes were observed for a year. Results were as follows: silver affected the host in the case of P-silver to a greater extent than in G-silver, especially on the $7^{\text {th }}$ day and after $2-4$ weeks. Nonetheless, the effect of silver weakened at 12 months after implantation. The presence of P-silver caused various histological reactions, while the decline of silver effect on the host was correlated with an increase in the sulfuration of silver.
\end{abstract}

Key words: Silver powder, Implant, Tissue reaction

Received Oct 5, 2007: Accepted Mar 15, 2008

\section{INTRODUCTION}

Silver is undoubtedly one of the most important metals being used since ancient times, as it has been developed and improvised for various applications in daily life. In the dental field, Ag and Ag-based alloys are widely used for restorations, as casting alloy and for other similar purposes ${ }^{1}$. Besides, silver is a wellknown bactericidal agent routinely used in clinical settings since the latter half of the $19^{\text {th }}$ century ${ }^{2)}$. In the medical field, most of its applications are based on the antimicrobial property of silver. Silver-coated polyester valves ${ }^{3)}$, silver-coated peritoneal catheters ${ }^{4}$, and silver-coated pins ${ }^{5}$ are some examples of medical instruments utilizing silver. Silver-containing hydroxyapatite ${ }^{6)}$, demineralized bone matrix treated with silver ${ }^{7}$, and glass ionomer cement with silver ${ }^{8)}$ are examples of the use of silver in biomaterials. Among these applications, silver dressings for wound treatment are well developed and studied ${ }^{2,9)}$.

While silver is well known to be cytotoxic ${ }^{5,6,10,11)}$, it has historically been used as medicine for mental illness, epilepsy and infectious diseases, among others ${ }^{12}$. Currently, it is still being used as a supplement ${ }^{12,13)}$. Moreover, with advances in nanotechnology, nanosilver ${ }^{14,15}$ is applied for the preparation of many consumer goods, such as sanitization agents and deodorizers. In the cases of argyria $^{16)}$ (pigmentation caused by silver ingestion) and tattoos (pigmented lesions caused by amalgam), silver remains in the body for an extended period, but causes no harm to the body tissues except for pigmentation ${ }^{17)}$.

In the present study, we focused on two characteristics of silver - the cytotoxicity of silver in culture medium and its harmless presence in the body tissues apart from pigmentation, as in the case of argyria. From a previous study on tattoos ${ }^{17)}, \mathrm{Ag}$ and $\mathrm{S}$ were found in various types of body tissues in varying amounts (size) $)^{18,19}$. Leveraging on these results, we sought to further examine the host reaction to silver in terms of long-term effect arising from size difference and sulfuration to clarify the contradictions in the cytotoxicity property of silver.

\section{MATERIALS AND METHODS}

\section{Silver particles for implantation}

Two types of silver particles (Wako, Japan) were used as implant materials. One was of maximum size at $45 \mu \mathrm{m}$ (granule-type silver; G-silver) and the other was of $100 \mathrm{~nm}$ size (powder-type silver; Psilver) based on commercial specifications. $\mathrm{Ag}_{2} \mathrm{~S}$ (Wako, Japan) particles were used as a control for sulfuration. The silver particles were observed using a scanning electron microscope (SEM; JSM-6330F, JEOL, Japan). $\mathrm{Ag}_{2} \mathrm{~S}$ particles were embedded in a resin (Technovit 4071, Heraeus Kulzer, Germany) and after polymerization, samples were ground with a grinder (RotoPol-35, Marumoto Struers, Japan) and finally polished to $0.1-\mu$ range roughness.

\section{Animal experiment}

Silver particles were implanted in 15 - to 20 -week-old rats (Std:Wistar/ST, SLC, Japan). Using an injection needle under intraperitoneal anesthesia with sodium pentobarbital $(30 \mathrm{mg} / \mathrm{kg}$ body weight; Nembutal, Abbott Laboratories, North Chicago, IL, USA), either granule-type silver (G-silver) or powder-type silver (P-silver) was injected under the skin of the right (P- 
silver) or left foot (G-silver). $\quad \mathrm{Ag}_{2} \mathrm{~S}$ powder, used as the control for sulfuration of silver, was also implanted in the $12^{\text {th }}$ month in the same way as the silver particles. Observations were performed on the $3^{\text {rd }}$ and $7^{\text {th }}$ days, $2^{\text {nd }}$ and $4^{\text {th }}$ weeks, and $3^{\text {rd }}, 6^{\text {th }}$, and $12^{\text {th }}$ months. Animals were divided into seven groups of three rats each, and both right and left feet were used for P-silver and G-silver implantations. A total of 23 rats, 21 rats for silver and two for $\mathrm{Ag}_{2} \mathrm{~S}$, were used.

The injection method that we developed for this experiment was as follows: two types of injection needles (25G, Terumo Co., Japan; 31G, Dentronics Co., Japan) were carefully attached as shown in Fig. 1. The smaller-sized needle acted as a cylinder to push out the silver particles. With this method, silver particles could be injected without any binder. The mass of silver particles for one injection was measured by a balance (AEL-40SM, Shimadzu, Japan). The skins were removed at $3^{\text {rd }}$ and $7^{\text {th }}$ days, $2^{\text {nd }}$ and $4^{\text {th }}$ weeks, and $3^{\text {rd }}, 6^{\text {th }}$ and $12^{\text {th }}$ months after implantation under an overdose of intraperitoneal sodium pentobarbital ( $200 \mathrm{mg} / \mathrm{kg}$ body weight). The
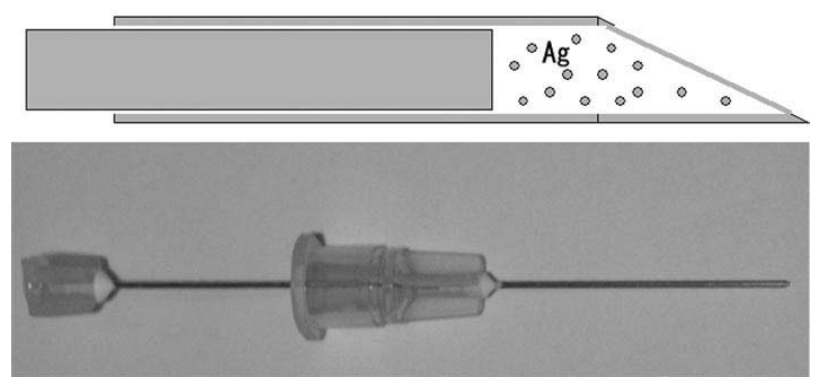

Fig. 1 Injection method of silver granules. Topmost panel: Scheme of injection method. Bottom picture: 25-G (left side) and 31-G injection needles (right side). tissues were fixed immediately in neutral formalin and embedded in paraffin wax according to routine histological procedures. Serial sections were cut (thickness: $4 \mu \mathrm{m}$ ) from each specimen, and then stained with hematoxylin and eosin (HE) for microscopic observation (BX50, Olympus, Japan).

The experiments were performed in accordance with the "Guidelines for Animal Experiments" of the Nippon Dental University School of Life Dentistry (Niigata, Japan).

\section{Observation and measurements}

Unstained sections were placed on a well-polished carbon stick according to the method of Watanabe et $a l .{ }^{20)}$ and on a normal glass slide. These sections and polished $\mathrm{Ag}_{2} \mathrm{~S}$ plate were investigated by an electronprobe microanalyzer (EPMA; JXA-9800R/RL, JEOL) with a wavelength dispersive spectrometer (WDS). Measurements were performed under the following conditions: accelerating voltage, $20 \mathrm{kV}$; beam current, $0.03 \mu \mathrm{A}$; and $1-\mu \mathrm{m}$ spot size. Scanning electron microscopy (SEM) images and compositional (COMP) images, quantitative data, qualitative data, and an element map were obtained from the analyses. After microscopic observation, the HE-stained sections were also investigated in the same way as the unstained sections and compared with HE-stained and EPMA data.

\section{RESULTS}

\section{Silver particles for implantation}

Two sizes of silver particles were used for implantation. For G-silver, SEM observation revealed that the silver granules ranged from $1 \mu \mathrm{m}$ to $45 \mu \mathrm{m}$ in size (Fig. 2a). In contrast, for P-silver, silver particles were of the order of $100 \mathrm{~nm}$ in size (Fig. 2b). Owing to size difference, weight of G-silver granules expressed by one injection was about $1 \mathrm{mg}$
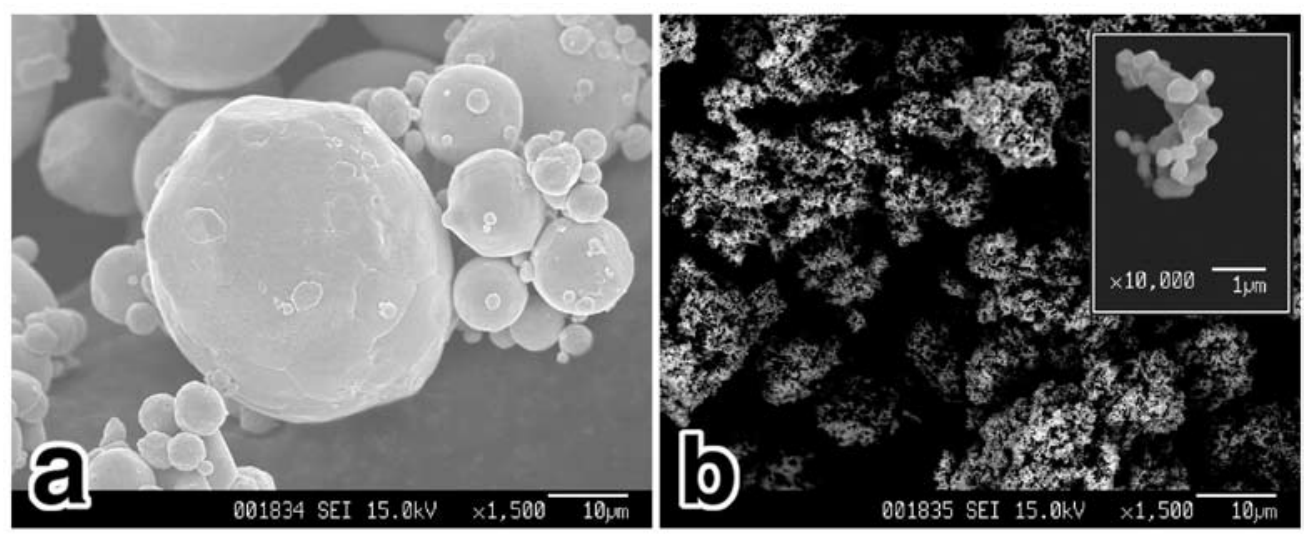

Fig. 2 Silver granules for implantation. (a) <45- $\mu \mathrm{m}$ size silver granules (G-silver); (b) 100-nm size silver particles (P-silver), where inset is an enlarged image of $\mathrm{P}$-silver particle. 


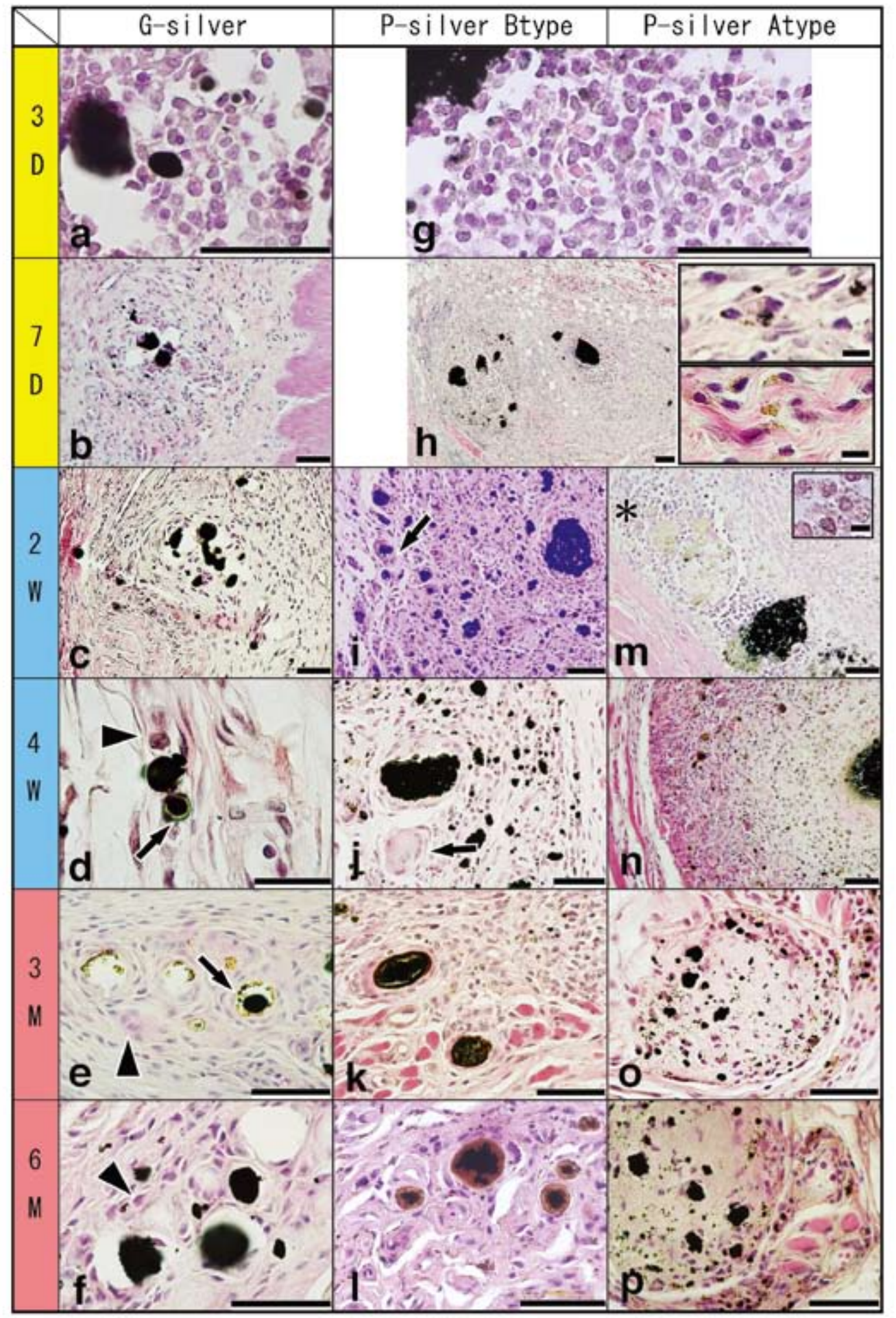

Fig. 3 Picture matrix of light microscopy findings of HE-stained sections on the $3^{\text {rd }}$ and $7^{\text {th }}$ days, $2^{\text {nd }}$ and $4^{\text {th }}$ weeks, and $3^{\text {rd }}$ and $6^{\text {th }}$ months after G-Silver and P-silver (A-type and B-type) implantations.

$\mathrm{a}-\mathrm{f}$ : G-silver implantation;

$\mathrm{g}-\mathrm{h}$ : P-silver implantation;

i-l: P-silver B-type implantation;

$\mathrm{m}-\mathrm{n}$ : P-silver A-type implantation;

Arrows (d, e): membrane-like substance; Arrow (j): giant cell; Arrow heads (d, e, f): X-cell (histiocyte?).

Upper inset of Fig. 3h: enlargement of center area; Lower inset of Fig. 3h: enlargement of Fig. 3h.

Inset of Fig. 3m: enlargement of area *.

Scale bars $(\mathrm{a}-\mathrm{p})=50 \mu \mathrm{m}$, scale bars $(\mathrm{h}-\mathrm{m}$, insets $)=5 \mu \mathrm{m}$. 
and that of P-silver was about $0.2 \mathrm{mg}$.

Histopathologic observation of silver implants

Figure 3 shows the histopathologic observations of HE-stained sections on the $3^{\text {rd }}$ and $7^{\text {th }}$ days, $2^{\text {nd }}$ and $4^{\text {th }}$ weeks, and $3^{\text {rd }}$ and $6^{\text {th }}$ months after implantation of G-silver and P-silver. The histopathologic features and their correlations are shown in a chart in Fig. 4. Figures 5-7 shows the histopathologic features, as well as SEM, COMP, and EPMA images of $\mathrm{Ag}$ and
MAP at 12 months after implantation.

Host reactions to the silver implants were classified into early stage $\left(3^{\text {rd }}-7^{\text {th }}\right.$ days; yellow bars in Figs. 3 and 4$)$, mid stage $\left(2^{\text {nd }}-4^{\text {th }}\right.$ weeks; blue bar in Figs. 3 and 4$)$, and late stage $\left(3^{\text {rd }}-12^{\text {th }}\right.$ months; red bar in Figs. 3 and 4).

1. Early stage $\left(3^{\text {rd }}-7^{\text {th }}\right.$ days; Figs. $3 a, b, g$ and $h$, and Fig. 4)

Histopathologic observation revealed a mix between

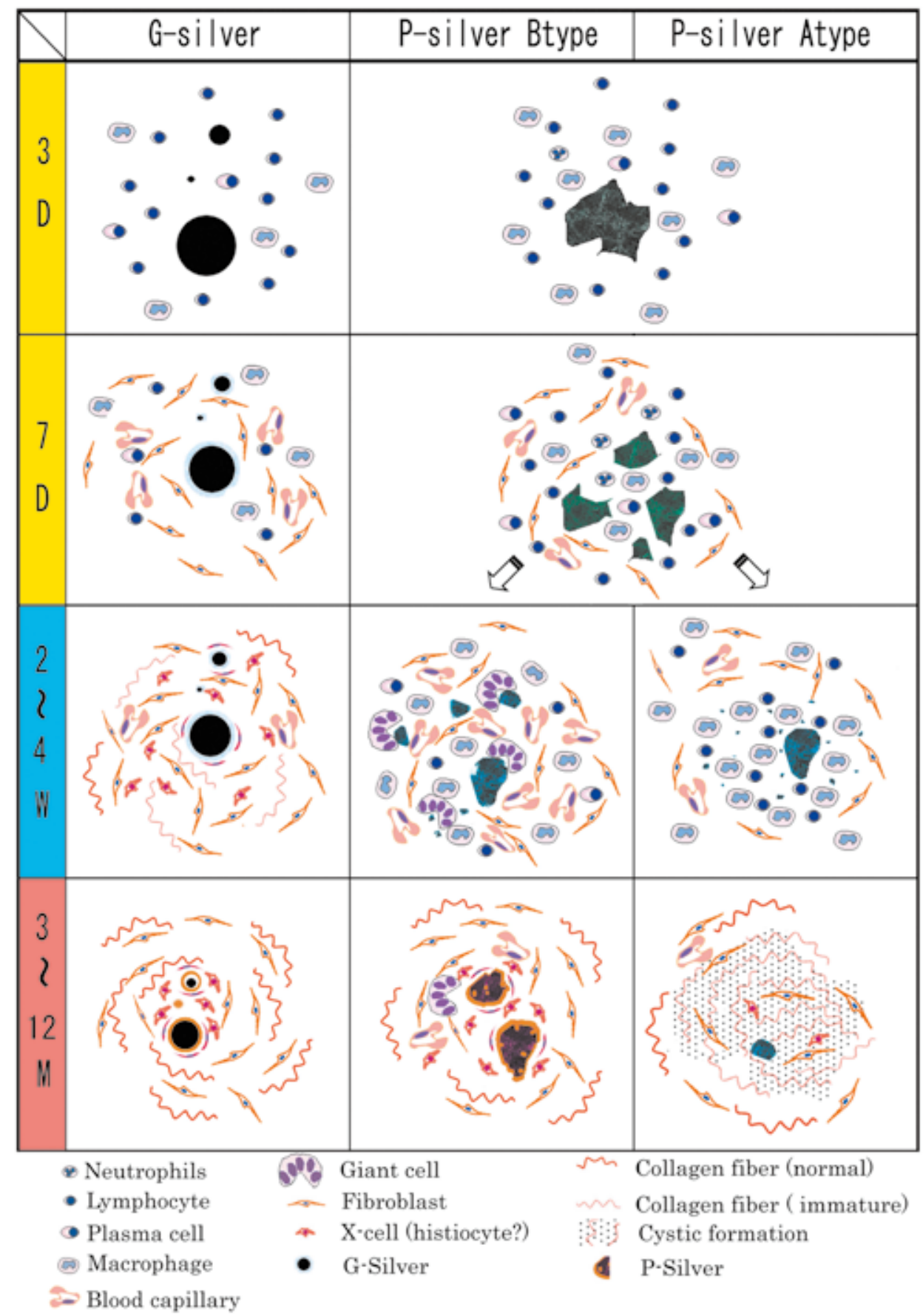

Fig. 4 Symbolized histopathological features of light microscopy findings of Fig. 3. 
stimulation from silver and minimum host reaction caused by injection injury. Lymphocyte and macrophage infiltration around the silver implants was found on the $3^{\text {rd }}$ day for both G-silver and Psilver. Some plasma cells were found in G-silver on the $3^{\text {rd }}$ day, but few neutrophils were present. However, on the $3^{\text {rd }}$ day in P-silver, both plasma cells and neutrophils were found and these increased by the $7^{\text {th }}$ day. On the $7^{\text {th }}$ day, some fibrous proliferation was found in both G-silver and P-silver. Fibroblastic cells with small granules were found (Fig. 3h, upper inset). Outside the granulation, small granules were also found with fibroblasts and collagen (Fig. 3h, lower inset).

2. Mid stage $\left(2^{\text {nd }}-4^{\text {th }}\right.$ weeks; Figs. $3 c, d, i, j, m$ and $n$,
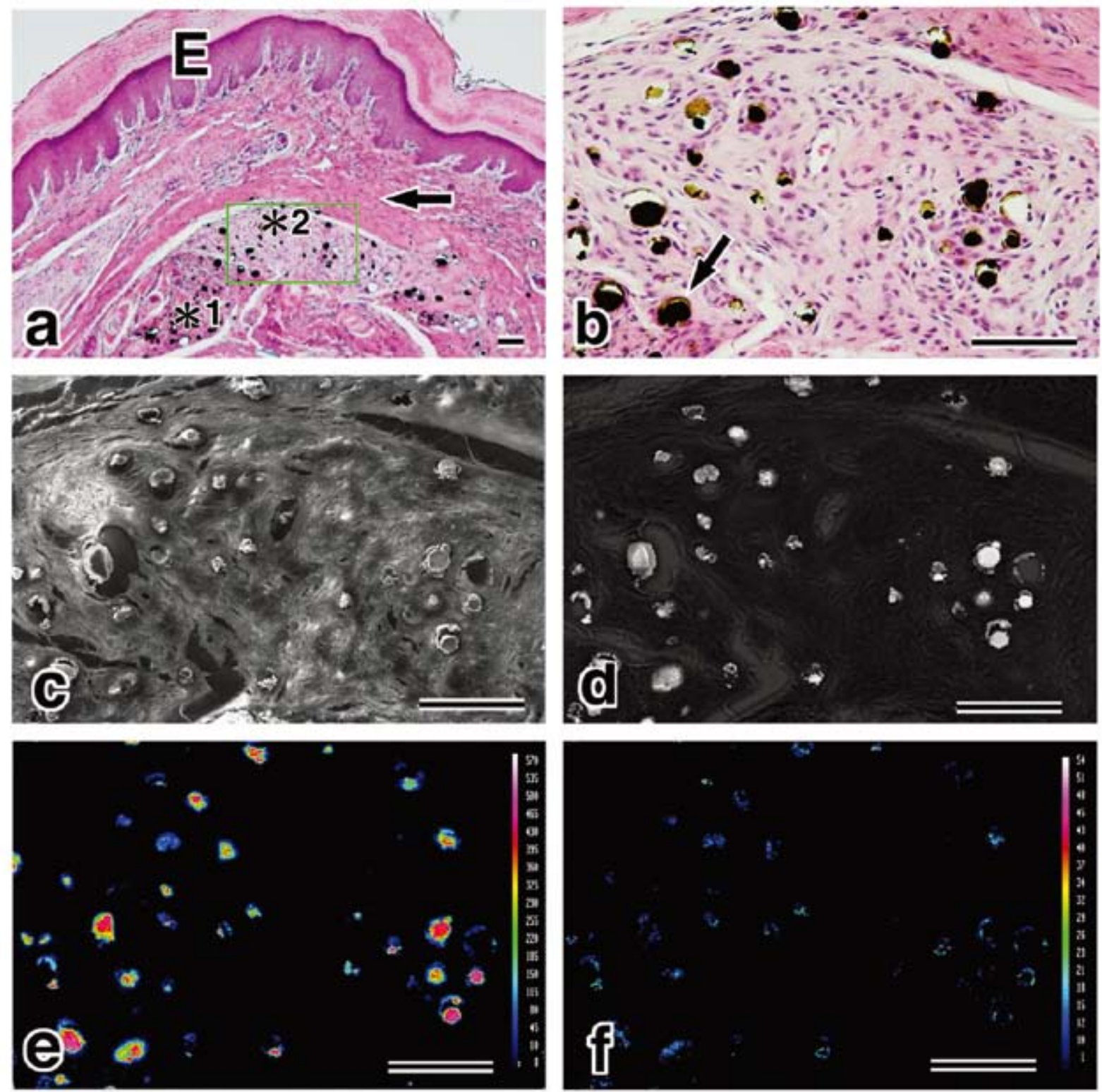

Fig. 5 Findings after 12 months of G-silver (<45- $\mu$ m size) implantation. Scale bars: $100 \mu \mathrm{m}$.

Light microscopy findings of HE-stained sections. Green square indicates the area of LIGHT, SEM, COMP, EPMA images. Arrow indicates normal connective tissue. E: epithelial.

Light microscopy finding as shown in green square of (a). Inflammatory cells were not found. Arrow shows membrane-like material.

SEM images same as (b).

COMP images same as (c).

EPMA map image of Ag same as (c). Same distribution as (d). Color bars: X-ray intensity of Ag.

EPMA map image of S same as (e). Part of (f) was the same as (e). Color bars: X-ray intensity of S. 
and Fig. 4)

Histopathologic observations were complex in this stage. The tissue was granulomatous and effect of silver on the host was strong. These findings were clear in P-silver, but not as clear in G-silver.
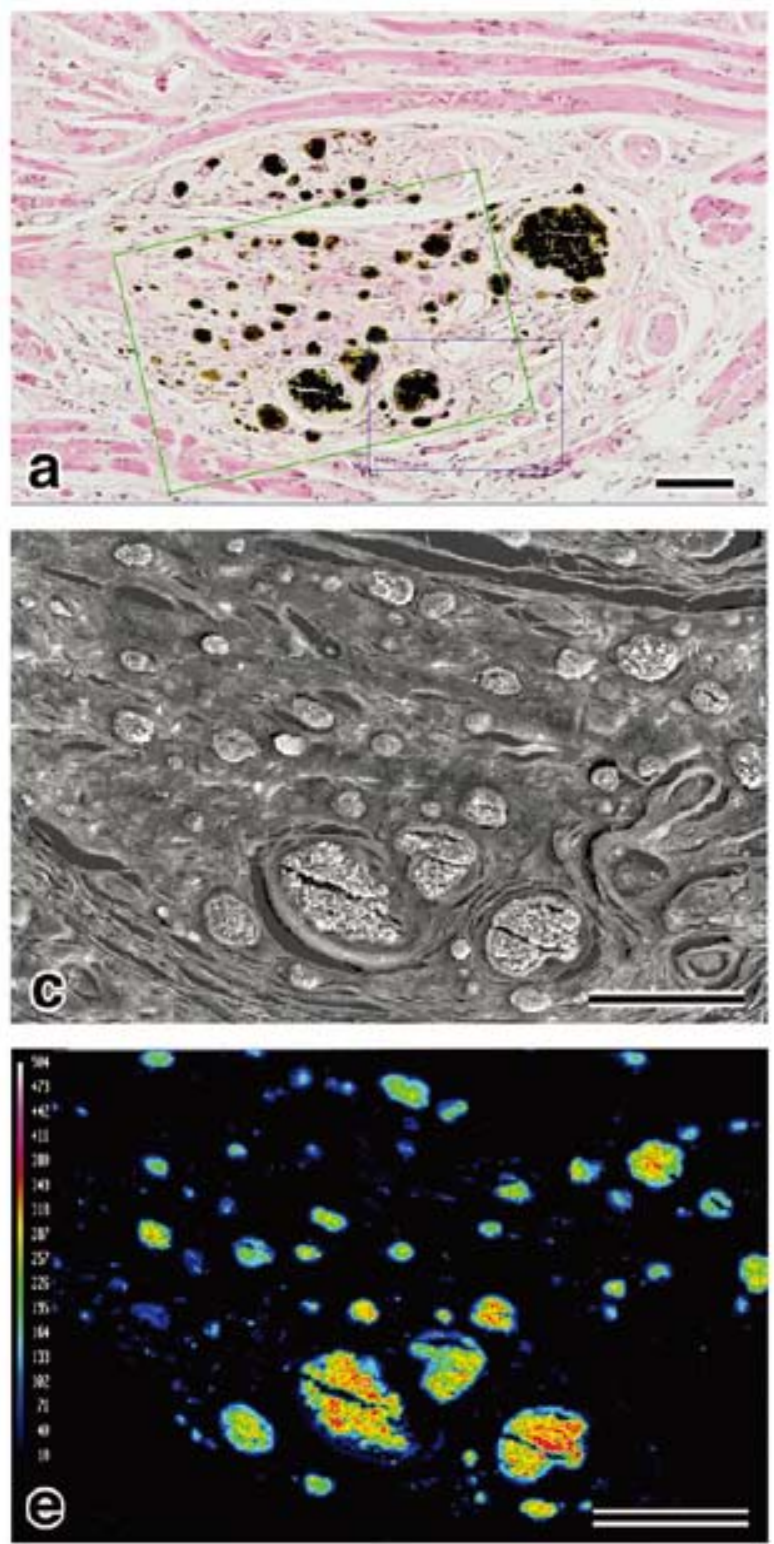

\section{2a) G-silver}

Most of the infiltration cells were not found. In their place was a weak fibrous capsule observed at 2 weeks after implantation (Fig. 3c). These findings became clearer at 4 weeks after implantation. Within the fibrous tissues, undefined cells (denoted as X-cells) which resembled fibroblasts (but had differences in the nuclei) and which also resembled histiocytes
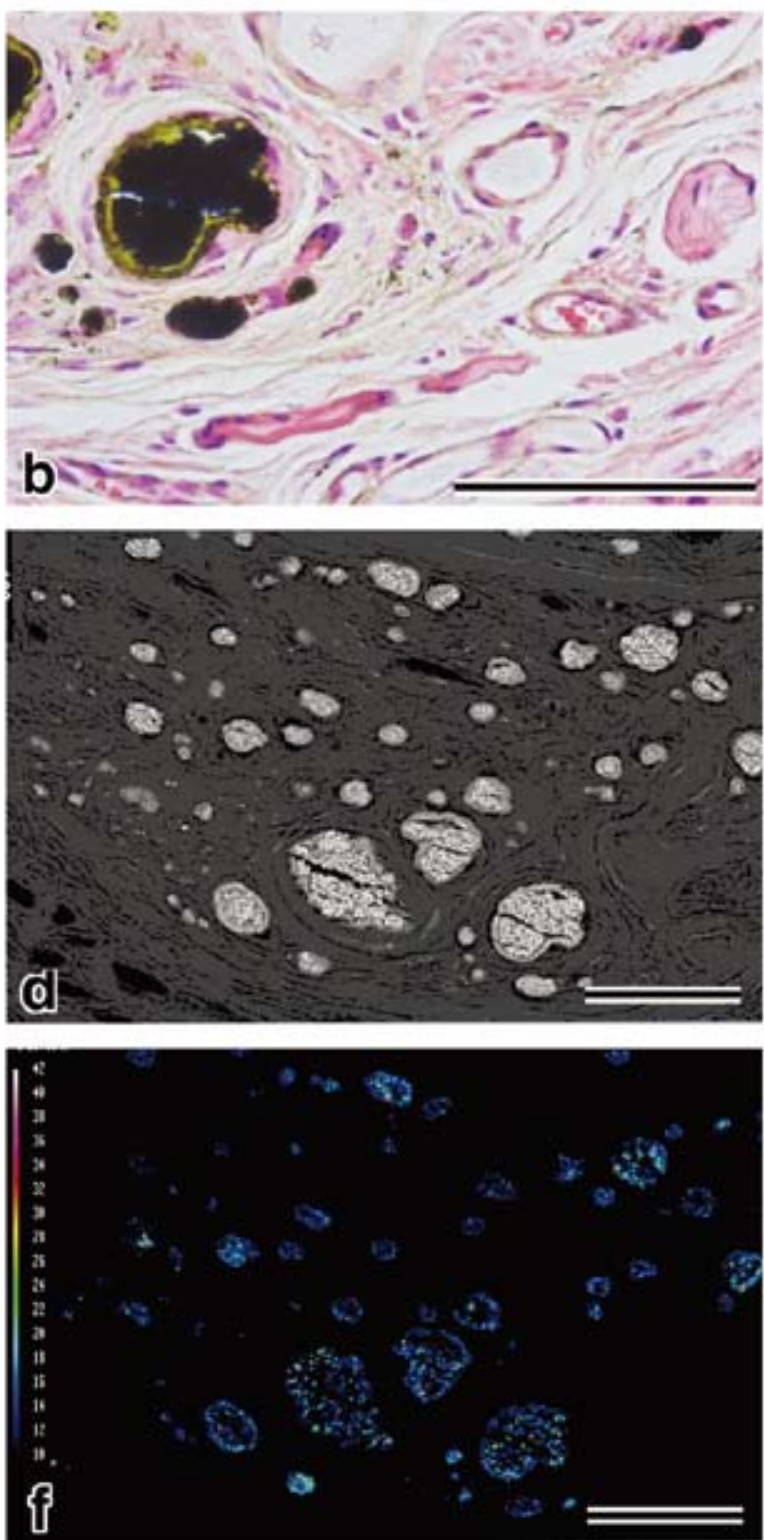

Fig. 6 Findings after 12 months of P-silver B-type (100-nm size) implantation. Scale bars: $100 \mu \mathrm{m}$. Light microscopy findings of HE-stained sections. Green square indicates the area of SEM, COMP, EPMA images, and purple square indicates the area of light microscopy images.

Light microscopy findings of HE-stained section as shown in purple square of (a). Inflammatory cells were not found. Arrow shows membrane-like materials.

SEM images same as the green square in (a).

COMP images same as (c). Diffused high electron-dense materials were observed in collagen.

EPMA map image of Ag same as (c). Same distribution as (d). Color bars: X-ray intensity of Ag.

EPMA map image of $\mathrm{S}$ as same as (e). Part of (f) was the same as (e). Color bars: X-ray intensity of S. 
(Figs. 3d, e, f: arrow head) were found. Around Gsilver, a membrane-like material, which was named originally by us, was sometimes observed from this stage (Fig. 3d: arrow).

2b) P-silver

Two types of observations were found - cystic type (A-type) and granulomatous type (B-type). Both types continued on to the next stage.

\section{P-silver B-type; granulomatous type}

Many macrophages, typical giant cells, lymphocytes, and small blood vessels were found with P-silver. A few fibroblasts and plasma cells were also noted at 2 weeks after implantation (Fig. 3i). The same picture was observed at 4 weeks after implantation.
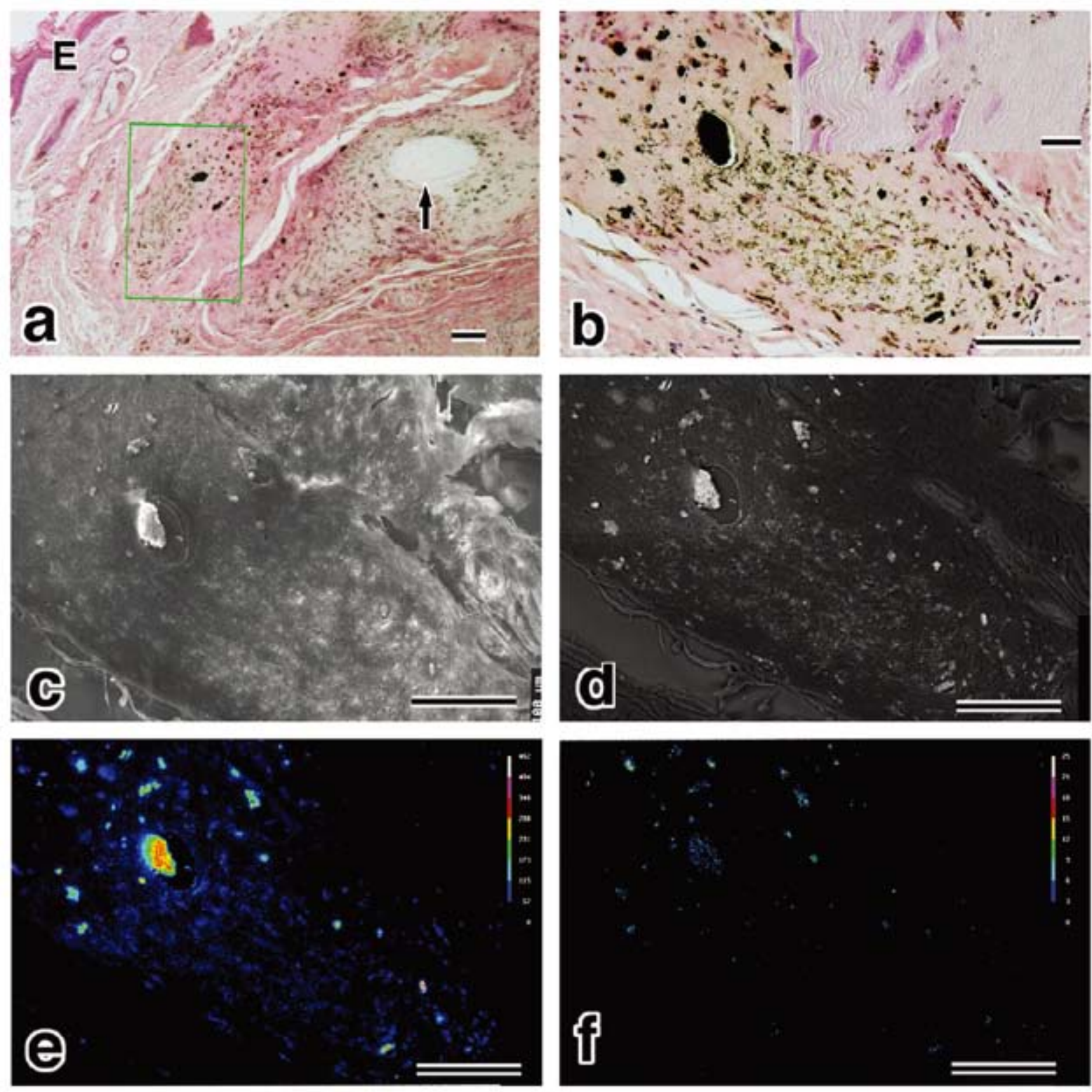

Fig. 7 Findings after 12 months of P-silver A-type (100-nm size) implantation. Scale bars: $100 \mu \mathrm{m}$.

Light microscopy findings of HE-stained sections. Green square indicates the area of Light, SEM, COMP, EPMA images. Arrow shows liquid degeneration.

Light microscopy findings of HE-stained sections as shown in green square of (a). Acellular but collagen-rich area. Inset of Fig. 7b: Enlargement of area near Fig. 7b; scale bars: $10 \mu \mathrm{m}$.

SEM images same as (b). Monotonous appearance of collagen structure.

COMP images same as (c). Diffused high electron-dense materials scattered in the collagen.

EPMA map image of Ag same as (c). Same distribution as (d). Color bars: X-ray intensity of Ag.

EPMA map image of $\mathrm{S}$ same as (e). Part of (f) was the same as (e). Color bars: X-ray intensity of S. 
Fibroblasts increased and typical giant cells were found (Fig. 3j: arrow).

\section{P-silver A-type; cystic type}

Numerous macrophages and lymphocytes were found around the silver implants and they showed cystic formation because of a lack of connective tissue matrix. Some macrophages had changed into foam- like cells (Fig. 3m, inset). Around the small cysts, fibroblasts with collagen were found. Typical giant cells were not seen. The same picture was found at 4 weeks after implantation. In some of the cystic tissues, a granulomatous appearance was found in the periphery, but the center area was still cystic with a few fibroblast cells and weakly HE-stained connective tissue. No typical giant cells were found
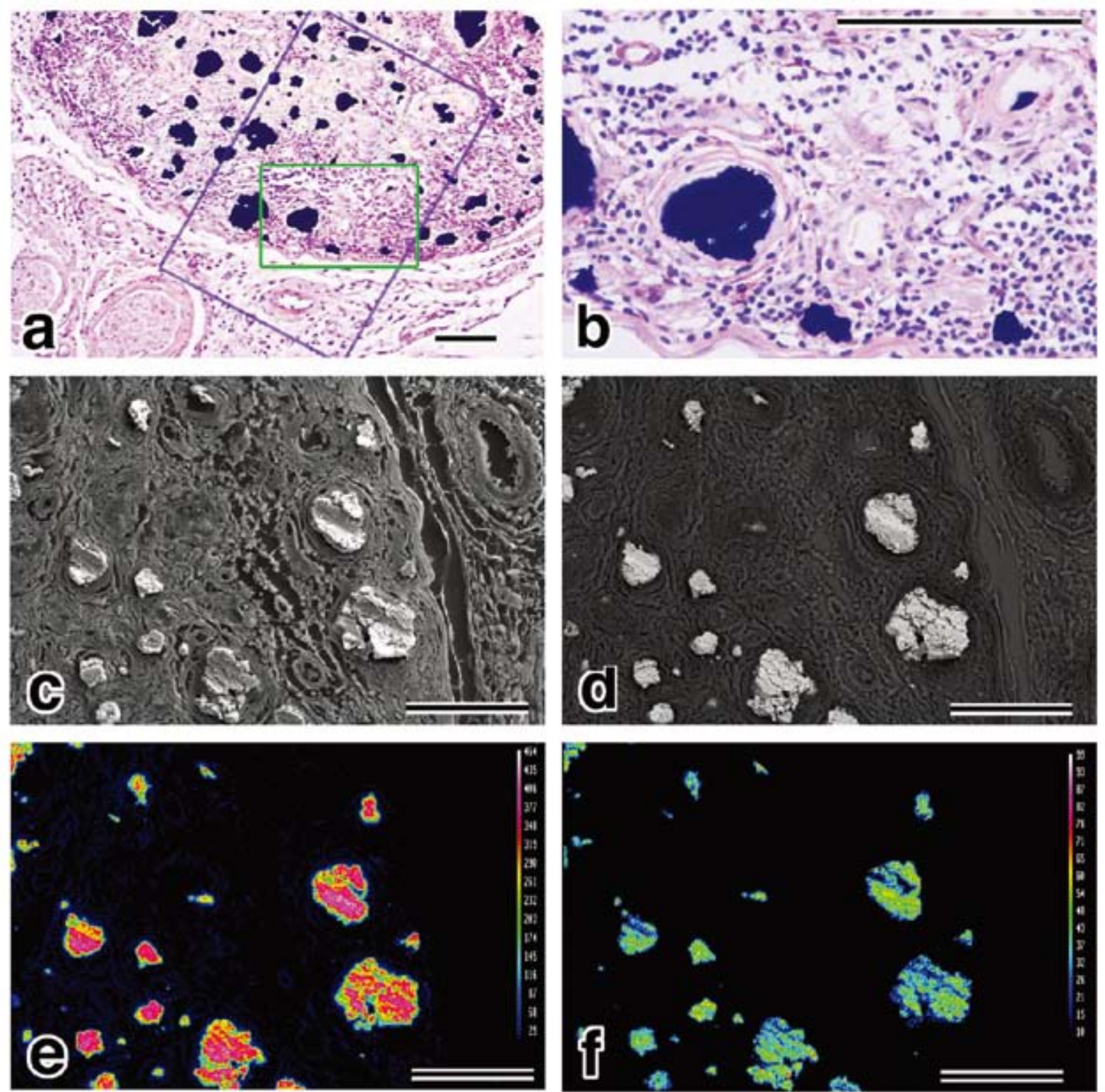

Fig. 8 Findings after 12 months of $\mathrm{Ag}_{2} \mathrm{~S}$ granule implantation as control. Scale bars: $100 \mu \mathrm{m}$.

Light microscopy findings of HE-stained sections. Purple square indicates the area of SEM, COMP, EPMA images and green square indicates the area of Light image.

Light microscopy findings as shown in green square of (a). Lymphocytes were found.

SEM images same as purple square in (b).

COMP images same as (c).

EPMA map image of Ag same as (c). Same distribution as (d). Color bars: X-ray intensity of Ag.

EPMA map image of S same as (c). Same distribution as (e). Color bars: X-ray intensity of S. 

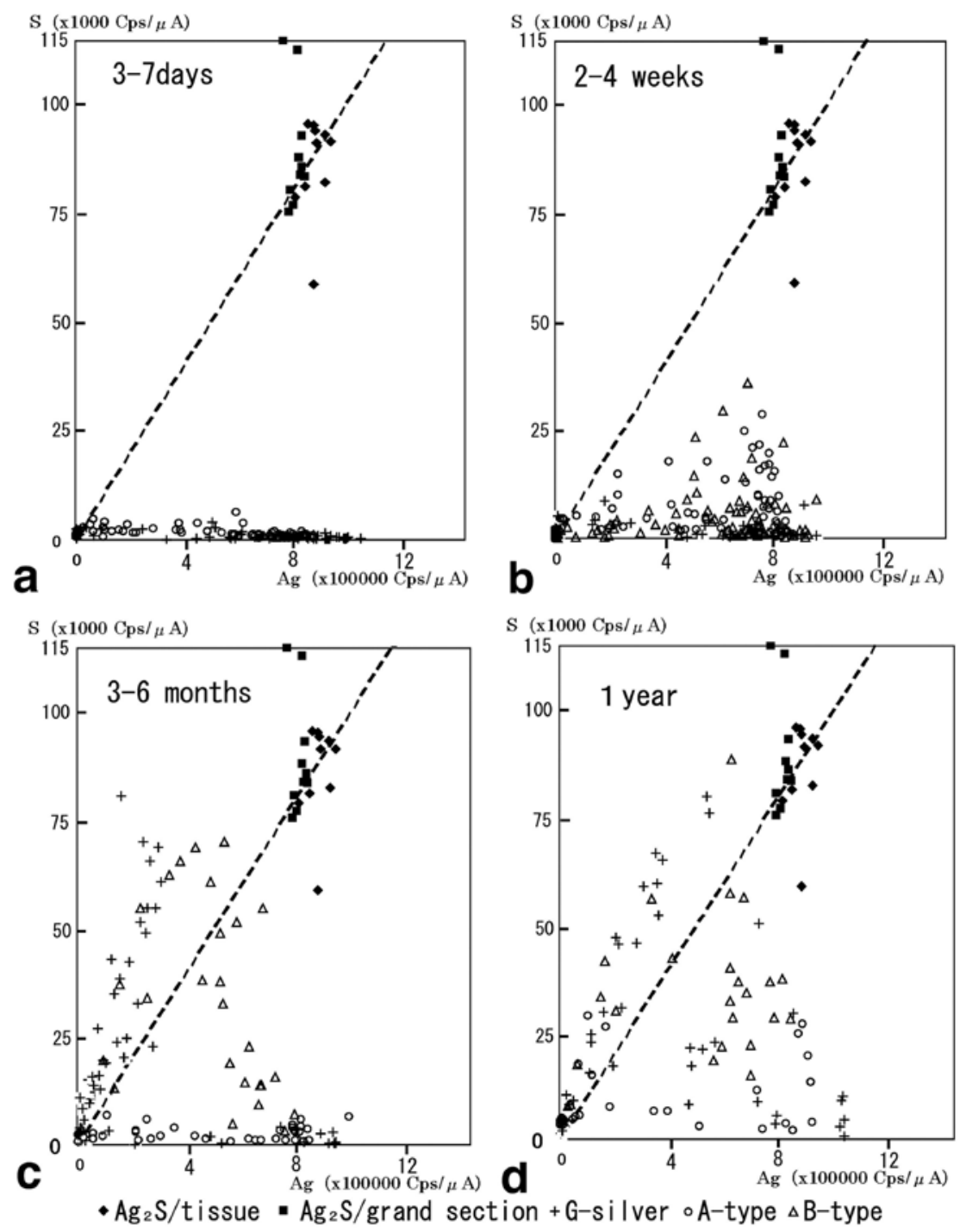

Fig. 9 Scatter diagrams of semi-quantitative analysis of $\mathrm{Ag}$ and $\mathrm{S}$ in the tissues of G-silver and P-silver implants. (a) - (d) black rhomboids: section of $\mathrm{Ag}_{2} \mathrm{~S}$ implant for 12 months; black squares: ground section of $\mathrm{Ag}_{2} \mathrm{~S}$ powder in resin; crossmarks: section of G-silver implant; circles: sections of P-silver A-type; triangles: sections of P-silver B-type; regression line (dashed line): from black rhomboids.

Point analysis of sections after 3-7 days of silver implantation.

Point analysis of sections after $2-4$ weeks of silver implantation.

Point analysis of sections after 3-6 months of silver implantation.

Point analysis of sections after 12 months of silver implantation.

(Fig. 3n).

3. Later stage $\left(3^{\text {rd }}-12^{\text {th }}\right.$ months; Figs. $3 e, f, k, l$, o and p, and Figs. 4-7)

Fibrosis or fibrous encapsulation of the foreign body occurred at this stage, and the effect of silver on the host became weak as time passed. In particular, findings in G-silver and P-silver B-type resembled each other as time passed. 3a) G-silver

Fibroblastic cells with collagen were found around the silver implant. Among the fibroblastic cells or near the silver implant, X-cells (perhaps histiocytes) were found. Most of the infiltration cells had disappeared. Fibrous granulation was noted up to the $12^{\text {th }}$ month after implantation. Histological observations were almost the same among the different sections of the same month and among sections of different months after implantation (Figs. 
3e and f; and Fig. 5). Indeed, from the $3^{\text {rd }}$ month to the $12^{\text {th }}$ month, only the density of collagen in fibrous granulation appeared to increase. These findings were evident from the two types of appearance: connective tissue was deeply stained by $\mathrm{HE}$ in one (Fig. 5a: ${ }^{*} 1$ ), while the other was weakly stained (Fig. 5a: *2). Membrane-like material directly in contact with the silver implant was noted. Sometimes, it was not present (Fig. 3f), but became clear and dark at 12 months after implantation. This membrane-like material showed sulfuration as observed in the COMP and EPMA images. No complete sulfuration was observed at the center areas of most G-silver implants.

3b) P-silver B-type; fibrous type

At this stage, fibrous granulation was found. However, a few inflammatory cells and giant cells were also evident in the $3^{\text {rd }}$ month after implantation (Fig. 3k). Fibrous granulation with numerous blood vessels was observed at 6 months after implantation with no inflammatory cells (Fig. 3l). Typical fibrous granulation similar to that in G-silver was found in the 12 th month after implantation. Varying degrees of membrane-like materials were found up to 12 months after implantation. Presence of silver and sulfuration were noted from the COMP and EPMA images. COMP and EPMA images showed sulfuration of accumulated P-silver (Fig. 6).

3c) P-silver, A-type; cystic type

Fibrous granulation was found up to 12 months after implantation. Under low magnification, the tissues appeared myxomatous or degenerative. However, in most cases, poorly developed collagen tissues were found, and scattered fibroblasts were seen (Fig. 7b, inset). Size of the cystic structure ranged from small (Fig. 3o) to large (Fig. 7). A few inflammatory cells were found up to the $6^{\text {th }}$ month, but were not found in the $12^{\text {th }}$ month after implantation. No giant cells and membrane-like materials were found at the $12^{\text {th }}$ month. Silver powder was scattered in the collagen matrix and some of it showed sulfuration, as seen in the COMP and EPMA images (Fig. 7).

4. Observation at 12 months after $\mathrm{Ag}_{2} \mathrm{~S}$ implantation As shown in Fig. 8, nodular granulomatous tissue with inflammatory cells such as lymphocytes was observed around $\mathrm{Ag}_{2} \mathrm{~S}$. COMP and EPMA images of the section served as control images showing full sulfuration of silver at a chemical level. The distributions of $\mathrm{Ag}$ and $\mathrm{S}$ intensities were almost the same.

Semi-quantitative analysis of $\mathrm{Ag}$ and $\mathrm{S}$ in the sections of $G$-silver and P-silver implants

The intensities of $\mathrm{Ag}$ and $\mathrm{S}$ in tissues after G- and P- silver implantation were semi-quantitatively measured using EPMA and shown in Fig. 9. All data were classified into the following groups: $3^{\text {rd }}-7^{\text {th }}$ days, early stage (total: 8 sections, 128 points); $2^{\text {nd }}-$ $4^{\text {th }}$ weeks, mid stage (total: 11 sections, 196 points); $3^{\text {rd }}-6^{\text {th }}$ months, late stage (total: 6 sections, 110 points); $12^{\text {th }}$ month, late stage (total: 7 sections, 95 points). All measurement points were randomly selected from high intensity areas of COMP images. If the selected area was large, the marginal area was also measured, thereby including the membrane-like materials. Data in P-silver implant and G-silver implant were again classified into A-type and B-type and plotted as crossmarks, circles, and triangles on the scatter diagrams of $\mathrm{Ag}$ and $\mathrm{S}$ intensities. Quantitative information of $\mathrm{Ag}$ and $\mathrm{S}$ in the tissue at 12 months after implantation of $\mathrm{Ag}_{2} \mathrm{~S}$ and ground section of $\mathrm{Ag}_{2} \mathrm{~S}$ was plotted on each plate as a standard mark.

The ratios of $\mathrm{Ag}$ and $\mathrm{S}$ intensities in the tissue and polished section were almost the same. The broken line on the graph shows the average intensities of $\mathrm{Ag}$ and $\mathrm{S}$ in $\mathrm{Ag}_{2} \mathrm{~S}$ implant sections, and the area above the broken line in the graph shows the S-rich condition in comparison to $\mathrm{Ag}_{2} \mathrm{~S}$. There were many points above the broken line at 3-6 months after implantation, and this tendency was more obvious in the cases of P-silver B-type implant and G-silver implant. At $3^{\text {rd }}-7^{\text {th }}$ days and $2^{\text {nd }}-4^{\text {th }}$ weeks, there were many points below the broken line, hence indicating S-poor condition. This inclination was more apparent in the case of G-silver. The distribution patterns of points at $3^{\text {rd }}-6^{\text {th }}$ months and at the $12^{\text {th }}$ month resembled each other. However at the $12^{\text {th }}$ month, fewer points were seen near the Ag axis (S-poor condition) than in the $3^{\text {rd }}-$ $6^{\text {th }}$ months.

\section{DISCUSSION}

While silver has long been considered safe for use in dentistry and other fields, it is also known to exhibit cytotoxic and antimicrobial effects ${ }^{6,21)}$. However, the cases of argyria and amalgam tattoos contradict expectations in that $\mathrm{Ag}$ can remain in the tissue for a long time without causing harm to the host. In most studies that investigated the cytotoxicity of silver and other metals, cell culture was employed ${ }^{5,10,22)}$. To understand the aforementioned contradictions presented by argyria and amalgam tattoos, rational studies such as amalgam implantation or implantation of silver-treated material would be a bold but helpful experimental strategy.

With amalgam, many components other than silver - such as $\mathrm{Hg}, \mathrm{Sn}$, and $\mathrm{Cu}-$ are included. With silver-treated implant materials, complexity could arise from mechanical factors. With respect to 
the experimental objective of investigating silver cytotoxicity, it would surely be more expedient to study the reaction of pure silver to the host. When performing such a study, the size selection of silver particles is an important consideration. With aggregates of large-sized silver particles (in the order of $\mathrm{mm})^{23)}$, the host would inevitably experience the initial trauma of injection of the silver.

Nanotechnology is a very promising field for generating new applications in medicine, and of which nanosilver (i.e., nano-sized silver) is a prominent product. Nanosilver exhibits strong antibacterial activity ${ }^{15}$ ) and is thus a choice implant material. However, the drawback is that nanosilver is difficult to manage without a binder ${ }^{14)}$. Therefore, in this study, apart from P-silver (in the order of 100 $\mathrm{nm}$ size), G-silver (below $45 \mu \mathrm{m}$ size) - which was bigger than usual host cells and P-silver - was also selected as it could be the target of cell phagocytosis.

\section{Histological findings}

Host reactions to the silver implants were grouped into three categories: early, mid, and late stages. The findings in this study almost corresponded with the normal stages of inflammation. In particular, Psilver B-type exhibited these stages most explicitly. On the overall, host reactions induced by $\mathrm{P}$-silver were stronger than that by G-silver. In the case of $\mathrm{P}$-silver, the reaction by A-type was stronger than that by B-type. These differences might be attributed to silver leaching, whereby the extent of leaching was in the following descending order: dispersed silver (P-silver, A-type) > aggregated silver (P-silver, Btype) $>$ G-silver.

In the early stage $\left(3^{\text {rd }}-7^{\text {th }}\right.$ days), there were no significant differences between G-silver and P-silver on the $3^{\text {rd }}$ day. However, a clear difference appeared on the $7^{\text {th }}$ day whereby host reaction was weak for Gsilver on the $7^{\text {th }}$ day. These findings showed that the effect of P-silver was stronger than G-silver. At the same time, initial trauma from the injection injury was probably mild - at least according to the level of host reaction to G-silver at the $7^{\text {th }}$ day. However, it remained unclear why lymphocytes - instead of neutrophils - mainly occupied the lesion.

In the mid stage, two types of findings surfaced for P-silver: typical granulomatous tissue with giant cells (B-type) versus cystic granulation without any giant cells (A-type). One reason for this distinction (A and B types) might stem from the distribution of $\mathrm{P}$-silver that stimulated the host tissue. With Btype, most of the silver powder particles were well packed in several sizes. On the other hand, in Atype, some of the silver particles were scattered in the tissue. A certain threshold of $\mathrm{Ag}^{+}$could have exerted cytotoxic effects on fibroblasts and endothelial cells, which were the main components of small vessels in granulomatous tissue. Alternatively, certain cytokines from macrophages, which were affected directly or indirectly by $\mathrm{Ag}^{+}$could have affected tissue differentiation or cell infiltration ${ }^{24}$. However, these histological behaviors require further investigation.

In the late stage, the host reactions seemed to resemble those of the healing period of inflammation or fibrous encapsulation of foreign body, especially with P-silver B-type. At the $12^{\text {th }}$ month, both Gsilver and P-silver showed the same appearance with rich collagenous tissue. Indeed, the effects of both Gsilver and $\mathrm{P}$-silver-B-type weakened at the $12^{\text {th }}$ month. However, histiocyte-like cells - which were found in the late stage of amalgam ${ }^{24}$ - existed around both types of silver implants and were named $\mathrm{X}$-cells in this study. This showed that there was weak stimulation from silver even at the $12^{\text {th }}$ month. The reason behind the weakened silver effects on the host could be related to the sulfuration of silver as shown in Fig. 9.

At this stage, P-silver A-type showed a myxomatous appearance under low magnification. Collagen bundles were not developed and density of fibroblasts was poor in comparison with usual connective tissues. As the nuclei of the fibroblasts looked active and not degenerative (Fig. 7b), A-type tissues were therefore not degenerative. One possible cause for this cystic finding could be due to a lack of vascular tissues, which was another characteristic finding of A-type. The direct or indirect effects of $\mathrm{Ag}^{+}$ could have stimulated fibroblasts to induce collagen generation or apoptosis of fibroblasts ${ }^{25)}$ or restricted endothelial differentiation, but no evidences were found for these speculations.

In this report, histopathologic observation areas were mainly restricted to areas where silver aggregation was found. However, on microscopic observation, the color of skin where silver was injected turned black and that the darkened area spread over time. This effect resulted in the same appearance at the $12^{\text {th }}$ month for both G-silver and P-silver. Pertaining to the investigation of silver cytotoxicity, amalgam was a helpful option. Ag was found in regional lymph nodes in a previous amalgam experiment ${ }^{26)}$. In this experiment, $\mathrm{Ag}$ was not found in regional lymph nodes or other organs such as the spleen or kidney. However, around the silver aggregates, some small granules with collagen or fibroblast cells (like those on the right side of Fig. 3h) were found in almost all the cases. Thus, most of the silver remained near the injection site in the form of so-called "tattoo". In this study, the amount of $\mathrm{Ag}$ was too small for another organ to be investigated. In other words, the cytotoxicity of Ag remains to be a topic to be pursued and examined. 


\section{Sulfuration of silver}

For investigation on sulfuration, the key investigative target would be the membrane-like material - which was found in both G-silver and P-silver (Btype) at the late stage. The membrane-like materials were not the same in appearance at the beginning, but became the same by the $12^{\text {th }}$ month. They were found at the periphery of the silver granules. However, the binding material, seen near the silver particles of B-type, could have the same components as the membrane-like materials. From the histological appearance and EPMA information, they contained $\mathrm{Ag}$ and $\mathrm{S}$, with the rest of the components probably derived from the host.

In the case of argyria, White et al. ${ }^{13)}$ demonstrated the presence of silver with $\mathrm{S}$ and Se in the base membrane and elastic fibers. Aoyagi and Katagiri ${ }^{17)}$ also reported the existence of silver and $\mathrm{S}$ in connective tissue without host reaction. Based on these reports, Ag could have bonded to the host substance through the connection of $\mathrm{S}$. If so, the effect of $\mathrm{Ag}^{+}$would be reduced. Having said this, the S-rich condition in comparison to $\mathrm{Ag}_{2} \mathrm{~S}$ was observed only in the late stage (Fig. 9). Therefore, other materials with thiol groups, such as superoxide dismutase (SOD) ${ }^{24)}$, should also be considered. Among the possible substances, metallothionein ${ }^{11,27)}$, an S-rich housekeeping protein and which reduces the effect of metal after binding with metal, is a highly probable candidate.

In the case of amalgam tattoos, there was no metallothionein near amalgam but it was found in the histiocytes nearby ${ }^{25}$. While direct bonding of $\mathrm{Ag}_{2} \mathrm{~S}$ could be considered, this might not be possible because the host reaction to $\mathrm{Ag}_{2} \mathrm{~S}$ implant was strong (Fig. 8). Aoyagi and Katagiri ${ }^{17)}$ examined Ag and S with collagen using polarized light microscopy. However, in our experiment, collagen with silver did not show any polarization. Therefore, there were probably many types of tissue reactions between $\mathrm{Ag}$ and/or S or S-containing substance.

As seen in Figs. 9c and d, the effect of sulfuration was low in the case of P-Silver A-type in the late stage. This finding would thus account for the tissue reaction in A-type silver. The intensity of $\mathrm{S}$ in A-type at $2^{\text {nd }}-4^{\text {th }}$ weeks (Fig. 9b) was higher than that at $3^{\text {rd }}-6^{\text {th }}$ months (Fig. 9c). This was probably because some of the A-type tissues resembled B-type tissue in the mid stage or that some sulfuration had occurred in the short term.

Selenium, having the same chemical property as $\mathrm{S}$, has been found to exist with $\mathrm{Ag}$ in pigmentation cases $^{13,28)}$. However, Se was not found in our experiment. Therefore, further studies are required to investigate this discrepancy.

\section{$A g$ ion $\left(A g^{+}\right)$}

From cytotoxicity point of view, the relation between $\mathrm{Ag}^{+}$and ROS (reactive oxygen species), SOD, mitochondria function, and other related factors have been well studied with nanosilver in cell culture ${ }^{24}$. As for Hidalgo and Dominguez ${ }^{10}$, they used human dermal fibroblasts with $\mathrm{AgNO}_{3}$ and reported inhibition of fibroblasts and DNA synthesis and/or loss of cell protein by $\mathrm{Ag}^{+}$. They demonstrated that the cytotoxicity of $\mathrm{Ag}^{+}$depended on $\mathrm{Ag}^{+}$density. In our experiment, it was impossible to measure the density of $\mathrm{Ag}^{+}$in the tissue. The difference in size of silver particles, G-silver $(<45 \mu \mathrm{m})$ and P-silver $(100$ $\mathrm{nm})$, mathematically meant 450 times' difference in surface area at the same mass. Teeguarden et al. ${ }^{29)}$ showed that 15-nanosilver exhibited an effect 4000 times greater than the micron-sized one. In other words, nanosilver presented strong toxicity ${ }^{29}$. The density of $\mathrm{Ag}^{+}$in an implanted area would almost be in proportion to the surface area of silver but not mass. The clear difference between P-silver and Gsilver at 7 days after implantation and other histological differences most probably stemmed from this difference in $\mathrm{Ag}^{+}$density.

\section{Ag size}

Kumazawa et al. ${ }^{30)}$ showed that fine Ti particles $(1-3$ $\mu \mathrm{m}$ ), smaller than neutrophils (about $5 \mu \mathrm{m}$ ), were phagocytosed by the cell and that the cytotoxic effect of $\mathrm{Ti}$ particles was size-dependent. In our experiment, macrophages as well as the usual fibroblasts were the key players in the phagocytosis of P-silver. Similar observations have been reported for amalgam cases ${ }^{19}$.

Besides, many typical giant cells were found in P-silver B-type, while only a few were observed in Gsilver and none in $\mathrm{P}$-silver A-type. The reason for these differences was not clear. It was likely that the local density of $\mathrm{Ag}^{+}$played an important role.

\section{EPMA application}

To analyze localization of silver in the tissues, autometallography ${ }^{31}$ - an application of photodeveloping technology - was used. This method was very sensitive, but was unable to measure many elements at the same time. Watanabe et al. ${ }^{20}$ demonstrated the successful use of EPMA in tissues, thereby leading to our employment of this method in the present study (Fig. 9). No large differences were observed between the intensity of $\mathrm{Ag}_{2} \mathrm{~S}$ in tissue and that in the ground section, which means that the intensity from the tissue was useful. As it was impossible to verify the exact positions between the map of EPMA and the microscopic image of the stained section, the map of EPMA after HE-staining was obtained to verify the exact positions (Figs. 58). The elements in the dye of $\mathrm{HE}$ and/or slide glass 
for $\mathrm{HE}$, in this case, were affected at a background level. Therefore, this method was useful not only in this study but also in other experiments that require information on elements.

\section{Injection method}

In this study, a new method to inject silver powder (P-silver and G-silver) subcutaneously using a needle was developed. With this method, silver powder could be implanted without surgical treatment. This would mean minimum host damage and minimum inflammation caused by injury. It must also be highlighted that only metal (silver), with no binding material or any anion, was used in this experiment. Therefore, this method might be useful not only for the study of silver but also for other metals or alloys.

\section{ACKNOWLEDGEMENTS}

The authors are grateful to Prof. H. Shimomura, Department of Oral Biochemistry, Nippon Dental University School of Life Dentistry at Niigata, for his encouragement and constant support. The authors are also grateful to Prof. S. Aoki, Department of Oral Biochemistry and Advanced Research Center, Nippon Dental University School of Life Dentistry at Niigata, for kindly allowing us the use of his laboratory. This research was supported by Research Promotion Grants (Nos. NDUF-06-22 and NDUF-05-22) from the Nippon Dental University.

\section{REFERENCES}

1) Saitoh S, Araki Y, Taira M. Sulfuration resistance of five experimental $\mathrm{Ag}-\mathrm{Pd}-\mathrm{Au}-\mathrm{Cu}$ alloys with low content of 10 or $12 \%$. Dent Mater J 2006; 25: 316331.

2) Wright BJ, Lam K, Burrell RE. Wound management in an era of increasing bacterial antibiotic. Am J Infect Control 1998; 26: 572-577.

3) Illingworth BL, Tweden K, Schroeder RF, Cameron JD. In vivo efficacy of silver-coated (Silzone ${ }^{\mathrm{TM}}$ ) infection-resistant polyester fabric against a biofilmproducing bacteria, Staphylococcus epidermidis. J Heart Valve Dis 1998; 7: 524-530.

4) Kathuria P, Moore HL, Prowant BF, Khanna R, Twardowski ZJ. Preliminary evaluation of silvercoated peritoneal catheters in rats. Dial 1995; 11: 189-192.

5) Bosetti M, Massè A, Tobin E, Cannas M. Silvercoated materials for external fixation devices: in vitro biocompatibility and genotoxicity. Biomaterials 2002; 23: 887-892.

6) Chen W, Liu Y, Courtney HS, Bettenga M, Agrawal CM, Bumgardner JD, Ong JL. In vitro anti-bacterial and biological properties of magnetron co-sputtered silver-containing hydroxyapatite coating. Biomaterials 2006; 27: 5512-5517.

7) Kramer SJ, Spadaro JA, Webster DA. Antibacterial and osteoinductive properties of demineralized bone matrix treated with silver. Clin Orthop Relat Res 1981; 161: 154-162.

8) Pissiotis E, Spângberg L. Reaction of bony tissue to implanted silver glass ionomer and a reinforced zinc oxide-eugenol cement. Oral Surg Oral Med Oral Pathol Oral Radiol Endod 2000; 89: 623-629.

9) Wright JB, Lam K, Buret AG, Olson ME, Burrell RE. Early healing events in a porcine model of contaminated wounds: effects of nanocrystalline silver on matrix metalloproteinases, cell apoptosis and healing. Wound Repair Regen 2002; 10: 141151.

10) Hidalgo E, Dominguez C. Study of cytotoxicity mechanisms of silver nitrate in human dermal fibroblasts. Toxicol Lett 1998; 98: 169-179.

11) Cosson RP. Heavy metal intracellular balance and relationship with metallothionein induction in the gills of carp. After contamination by $\mathrm{Ag}, \mathrm{Cd}$, and $\mathrm{Hg}$ following pretreatment with $\mathrm{Zn}$ or not. Biol Trace Elem Res 1994; 46: 229-245.

12) Gulbranson SH, Hud JA, Hansen RC. Argyria following the use of dietary supplements containing colloidal silver protein. Cutis 2000; 66: 373-374.

13) White JM, Powell AM, Brady K, Russell-Jones R. Severe generalized argyria secondary to ingestion of colloidal silver protein. Clin Exp Dermatol 2003; 28: 254-256.

14) $\mathrm{Yu}$ DG. Formation of colloidal silver nanoparticles stabilized by $\mathrm{Na}^{+}$-poly $(\boldsymbol{\gamma}$-glutamic acide)-silver nitrate complex via chemical reduction process. Biointerf 2007; 59: 171-178.

15) Chen X, Schluesener HJ. Nanosilver: a nanoproduct in medical application. Toxicol Lett 2008; 176: 1-12.

16) Chang AL, Khosravi V, Egbert B. A case of argyria after colloidal silver ingestion. J Cutan Pathol 2006; 33: 809-811.

17) Aoyagi H, Katagiri M. Long-term effects of Agcontaining alloys on mucous tissue present in biopsy samples. Dent Mater J 2004; 23: 340-347.

18) Zhang X, Gelderblom HR, Zierold K, Reichart PA. Morphological findings and energy dispersive X-ray microanalysis of oral amalgam tattoos. Micron 2007; 38: 543-548.

19) Eley BM, Cox SW. Renal cortical mercury levels associated with experimental amalgam tattoos: effects of particle size and amount of implanted material. Biomaterials 1987; 8: 401-403.

20) Watanabe K, Miyakawa O, Kobayashi M. New method for quantitative mapping of metallic elements in tissue sections by electron probe microanalyser. J Electron Microsc 2001; 501: 77-82.

21) Kraft CN, Hansis M, Arens S, Menger MD, Vollmar B. Striated muscle microvascular response to silver implants. A comparative in vivo study with titanium and stainless steel. J Biomed Mater Res 2000; 49: 192-199.

22) Sakai T, Takeda S, Nakamura M. The effects of particulate metals on cell viability of osteoblast-like cells in vitro. Dent Mater J 2002; 21: 133-146.

23) Zielke DR, Rio CE. Corrosion of silver cones in bone: a scanning electron microscope and microprobe analysis. J Endo 1975; 1: 356-360.

24) Lau JC, Jackson-Boeters L, Daley TD, WysockiGP, Cherian MG. Metallothionein in human gingival 
amalgam tattoos. Arch Oral Biol 2001; 46: 10151020.

25) Braydich-Stolle L, Hussain S, Schlager JJ, Hofmann MC. In vitro cytotoxicity of nanoparticles in mammalian germline stem cells. Toxicol Sci 2005; 88: 412-419.

26) Eley BM. Tissue reactions to implanted dental amalgam, including assessment by energy dispersive X-ray micro-analysis. J Path 1982; 25: 251-272.

27) Surowiak P, Paluchowski P, Dziegiel P, Wysocka T, Wojnar A, Spaczyń M, Zabel M. Lack of relationship between metallothionein (MT) expression and proliferation exponents in cells of primary ductal breast cancer of G2 grade of differentiation. Med Sci Monit 2004; 10: 300-305.

28) Venclíková Z, Benada OB, Bártová J, Joska L,
Mrklas L. Metallic pigmentation of human teeth and gingiva: morphological and immunological aspects. Dent Mater J 2007; 26: 96-104.

29) Teeguarden JG, Hunderliter PM,Orr G, Thrall BD, Pounds JG. Particokinetics in vitro: Dosimetry considerations for in vitro nanoparticle toxicity assessments. Toxicol Sci 2007; 95: 300-312.

30) Kumazawa R, Watari F, Takashia N, Tanimura Y, Uo M, Totsuka Y. Effects of Ti ions and particles on neutrophil function and morphology. Biomaterials 2002; 23: 3757-3764.

31) Zdolsek JM, Roberg K, Brunk UT. Visualization of iron in cultured macrophages: a cytochemical light and electron microscopic study using autometallography. Free Radic Biol Med 1993; 15: 1-11. 